\title{
Erratum: Kambezidis et al. Climate Change and Thermal Comfort in Greece. Climate 2021, 9, 10
}

\author{
Harry D. Kambezidis ${ }^{1, * \mathbb{D}}$, Basil E. Psiloglou ${ }^{2} \mathbb{D}$, Konstantinos V. Varotsos ${ }^{2}$ and $_{\text {Christos Giannakopoulos }}{ }^{\mathbb{D}}$ \\ 1 Atmospheric Research Team, Institute of Environmental Research and Sustainable Development, \\ National Observatory of Athens, GR-11810 Athens, Greece \\ 2 Institute of Environmental Research and Sustainable Development, National Observatory of Athens, \\ GR-15236 P. Penteli, Greece; bill@noa.gr (B.E.P.); varotsos@noa.gr (K.V.V.); cgiannak@noa.gr (C.G.) \\ * Correspondence: harry@noa.gr
}

check for

updates

Citation: Kambezidis, H.D.; Psiloglou, B.E.; Varotsos, K.V.; Giannakopoulos, C. Erratum: Kambezidis et al. Climate Change and Thermal Comfort in Greece. Climate 2021, 9, 10. Climate 2021, 9, 85. https://doi.org/10.3390/cli9050085

Received: 6 April 2021

Accepted: 26 April 2021

Published: 18 May 2021

Publisher's Note: MDPI stays neutral with regard to jurisdictional claims in published maps and institutional affiliations.

Copyright: (c) 2021 by the authors. Licensee MDPI, Basel, Switzerland. This article is an open access article distributed under the terms and conditions of the Creative Commons Attribution (CC BY) license (https:// creativecommons.org/licenses/by/ $4.0 /)$.
The author wishes to make the following corrections to the paper [1]:

1. Change in authorship (add Basil E. Psiloglou, Konstantinos V. Varotsos, Christos Giannakopoulos)

In the original paper [1], Basil E. Psiloglou, Konstantinos V. Varotsos and Christos Giannakopoulos were not included as authors in the published article.

2. Change in Authors' Contributions

Conceptualization, methodology, data curation, data analysis, writing-original draft preparation, writing-review and editing, H.D.K.; future Typical Meteorological Years conceptualization and development through the KRIPIS-THESPIA-II project, software and data curation, B.E.P.; provision of future meteorological and solar radiation data through the KRIPIS-THESPIA-II project, software and data curation K.V.V., and C.G.

3. Change in Acknowledgements

The authors are thankful to the Hellenic National Meteorological Service for providing meteorological data from 33 stations in the network in the period 1985-2014 with the purpose of generating the historical TMYs-MC used in this work through the KRIPISTHESPIA-II project (WP6). They also express their gratitude to the other members of the KRIPIS-THESPIA-II WP6 team for the generation of the TMYs, both historical and future: Dimitris Kaskaoutis, Kosmas Kavadias, Kalliopi Petrinoli, Ariadne Gavriil, and Dimitris Karagiannis.

4. Change in Conflicts of Interest

The authors declare no conflict of interest.

\section{Reference}

1. Kambezidis, H.D.; Psiloglou, B.E.; Varotsos, K.V.; Giannakopoulos, C. Climate change and thermal comfort in Greece. Climate 2021, 9, 10. [CrossRef] 